$25-30 \%$ during the Proterozoic and Phanerozoic; (2) crust-forming magmatic products originated in the mantle; (3) existing continental material had relatively little effect in modifying the composition of magmatic mantle products. Some took plate tectonic processes back to $3.8 \times 10^{9}$ years and correlated Archaean greenstones with Phanerozoic ophiolitic sequences and Archaean granitoids with products of present-day arc systems. Others pointed to geothermal and geochemical differences and argued either that if plate tectonics had existed in the Archaean, the processes were markedly different from those of the present; or that some other mechanism must have been involved.

Some interesting ideas were presented and several speakers dealt with particular aspects of accretionary processes. For instance, J.F. Dewey (Albany, New York), a staunch advocate of Precambrian plate tectonics, invoked the term 'para-oceans' and maintained that mantle processes leading to the formation of basins or paraoceans without reaching the true sea-floor spreading stage, probably make quantitatively important contributions to evolution of the continental crust. W.R. Dickinson (University of Tucson) suggested that sufficient variables exist in present-day plate tectonic processes to explain all the differences identified for older geological formations. Others, notably D.E. Karig (Cornell University), A.M. Ziegler (University of Chicago), W. Hamilton (US Geological Survey, Denver), F. Barker (USGS, Denver), R.S. Thorpe (Open University) and G.C. Brown (Open University), discussed the role of existing crust in modifying mantle products either by the incorporation of subducted sediments or by reaction between ascending magmas and the crust. Most argued that the modifications were quantitatively minor, though it was evident that a fuller understanding of island arc and back-arc processes (J. Tarney, University of Leicester) is essential. In this respect, B. Windley's (University of Leicester) report on an upended Upper Cretaceous arc in the Himalayas (traversed by the new Karakoram Highway), was particularly appropriate (see box). By way of a corrective to those advocating large scale relative movements of cratonic blocks in the Proterozoic, D.J. Dunlop (University of Toronto, Ontario) pointed out that the palaeomagnetic record remains inconclusive.

Geological, geophysical and geochemical modelling attempts to place restraints on the shape, form and composition of continental crust and hence on the processes that form it. E.R. Oxburgh (University of Cambridge) and P.R.A. Wells (Shell, The Hague) presented thermal models relating to the thickness of continental lithospheric plates and the

I.G. Gass and J.B. Wright are in the Department of Earth Sciences at the Open University.

\title{
An island arc section in the Himalayas
}

\section{from Mike Coward, Geoffrey King and Brian Windley}

THE newly-constructed Karakoram Highway in Pakistan provides access to (and excellent exposure of) the magnificent Kohistan island arc section. A recent conference of an International Geodynamics Working Group* provided much information on the geological and structural setting of the Kohistan island arc as well as a visit to the site.

At the conference Qasim Jan and $\mathrm{K}$. Tahirkheli (University of Peshawar) and the French group from the Geology Department, Montpellier University described the structure cut by the Karakoram Highway in the Kohistan Himalayas. They interpreted this as a complete section of a late Cretaceous island arc, standing on end. At the base of the section, garnet and pyroxene rocks interpreted as mantle are overlain by amphibolite and metagabbro. Above this is a huge elongate layered metanorite lopolith at least $15 \mathrm{~km}$ thick and $300 \mathrm{~km}$ long. Above this and apparently related to it are calc-alkaline intermediate and acid intrusive and volcanic rocks topped by a magnificent section of pillow lavas and volcanic derived sediments.

This is the first complete section of continental style crust to be identified. It

*Held at the University of Peshawar, Pakistan on 19-27 November, 1979.

extent of under and overplating above destructive margins. Oxburgh argued that the continental lithosphere can be at most $250 \mathrm{~km}$ thick, a conclusion contested by T.H. Jordan (Scripps Institution, San Diego) who presented evidence that the lithosphere (tectosphere) beneath cratonic areas may be up to $400 \mathrm{~km}$ thick. However, this geologically reasonable model was strongly challenged by other geophysicists in the audience. Two contributions by H.D. Holland (Harvard University) and S.R. Taylor (Australian National University) respectively discussed the role of the atmosphere and hydrosphere and of sediments in crustal evolution; and J.V. Smith (University of Chicago) rounded off an interesting session with some speculations about the first $800 \mathrm{Ma}$ of geological time (between 4,600 and 3,800 Ma ago).

The afternoon of the second day proved the most controversial part of the whole meeting. Chaired by the unashamedly 'accretionist' S. Moorbath (University of Oxford) it opened quietly enough with an exposition of the role of fluids, both magmatic and volatile, in crustal evolution (G.N. Hanson, State University of New York, Stony Brook). R.L. Armstrong (University of British Columbia) ably and entertainingly stated the 'conservationist' case, using evidence from a wide variety of sources, to support his thesis that the is still apparently being emplaced as a massive thrust slab imbricated between the plate to the north carrying the Karakoram granite and thrust slabs of the Indian subcontinent. During the thrust process, which continued seismicity suggests is still active, the Kohistan sequence has been tilted so that the layering and bedding are vertical.

Future work on the exposed section will allow the chemical differentiation process in island arcs to be studied. Some aspects of the process are already obvious and interesting. Since the lopolith from which the higher level andesitic rocks derive is basic in composition, it seems that andesitic differentiation to form calc-alkaline rocks occurs at crustal levels rather than deeper in the mantle and the details of this can be studied.

Further studies of structure and seismicity should also elucidate the processes whereby dense material can be lifted by thrust processes to high crustal levels and may also indicate the depth at which decoupling occurs in lower lithosphere.

Mike Coward is in the Department of Earth Sciences, University of Leeds, Geoffrey King is in the Department of Geodesy \& Geophysics, University of Cambridge, and Brian Windley is in the Department of Earth Sciences, University of Leicester.

continental crust has not grown significantly since early Precambrian times, but has been quantitatively recycled since it was first fully formed early in the Earth's history.

The discussion which followed showed this school of thought to be in a minority, but it also demonstrated that the difference between the two schools may be more imagined than real: few would dispute that there is some recycling of continental crust, the question seems to be simply: 'how much'. On the basis of some crustal modelling, R.K. O'Nions (University of Cambridge) argued that although most continental crust formed by about $3 \times 10^{9}$ years ago, the relationships between $\mathrm{Nd}$, $\mathrm{Sr}$, and $\mathrm{Pb}$ isotopes are consistent with $\mathrm{a}$ small amount of crustal recycling.

Finally D.P. McKenzie (University of Cambridge) focused on the geophysical constraints on models for the early Precambrian, when heat generation was much greater than now, and provided a salutary reminder that crust and lithosphere cannot be treated separately when discussing crustal evolution.

All in all, there was little if any 'crossing the floor' at this meeting, the protagonists seem to have gone their separate ways unconvinced by each other's counterarguments. But this was a timely, entertaining and authoritative review of the contrasting lines of thought. 